\title{
CrimRxiv
}

\section{Entre méfiance et défiance : les Autochtones et la justice pénale au Canada}

\author{
Mylène Jaccoud
}

Published on: Apr 27, 2020

DOI: $10.21428 / c b 6 a b 371.98434 b 7 c$

License: Creative Commons Attribution 4.0 International License(CC-BY 4.0). 
